\title{
Migration, memory and mythification: relocation of Suleymani tribes on the northern Ottoman-Iranian frontier
}

\section{Erdal Çiftçi}

To cite this article: Erdal Çiftçi (2018) Migration, memory and mythification: relocation of

Suleymani tribes on the northern Ottoman-Iranian frontier, Middle Eastern Studies, 54:2, 270-288, DOI: $10.1080 / 00263206.2017 .1393623$

To link to this article: https://doi.org/10.1080/00263206.2017.1393623

曲 Published online: 06 Nov 2017.

Submit your article to this journal $\pi$

Џll Article views: 361

View Crossmark data $\complement$ 


\title{
Migration, memory and mythification: relocation of Suleymani tribes on the northern Ottoman-Iranian frontier
}

\author{
Erdal Çiftçi (iD)

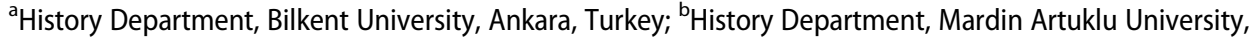 \\ Mardin, Turkey
}

Although some researchers have studied the relationship between hereditary Kurdish emirs and the Ottoman central government, there has been little discussion of the role played by Kurdish tribes, and Kurdish tribes in general have been omitted from scholars' narratives. Researchers have mostly discussed how Idris-i Bidlisi became an intermediary between the Ottoman central government and the disinherited Kurdish emirs, some of whom had been removed from power by the Safavids. In this article, we will not focus on the condominium between the Ottoman central government and the Kurdish emirs, but rather, we will draw attention to the roles played by the Kurdish tribes - specifically, the role played by the Suleymani tribes during the period dominated by local political upheaval in the sixteenth century. We will show that Suleymani tribes were some of the most prominent actors in the political shifts of sixteenth-century Ottoman Kurdistan. In addition, this study will analyze the memory of relocation of Suleymani tribes that was still alive during the nineteenth century as well as the tribal myth concomitant to this process.

The Ottomans captured Kurdistan from the Safavids during the second quarter of sixteenth century by obtaining the support of local Kurdish powers, and they strengthened their hold on these newly conquered territories at the Iranian frontiers with the help of allied tribes such as the Suleymani Kurds. The Ottoman central government used the relocation of nomadic groups as a tool to reorganize and strengthen their hold on the newly conquered region, a continuation of a policy of displacement and repopulation for political purposes that had been practiced in the Ottoman Balkans in the fifteenth century. Similarly, the Ottoman central government supported the relocation of the Suleymani tribes as a tool of re-organization in newly conquered territories of the northern OttomanIranian frontier region during the sixteenth century. As Halil Inalcik has shown, security concerns provoked the mass deportation of nomadic tribes toward the Balkan territories. Although Inalcik discusses deportation of nomads as an Ottoman method of conquest in the Balkans in the fifteenth century, he omits the Ottoman expansion against the Safavids from his study, and he does not compare and contrast the way in which this method of conquest was used on the eastern frontiers of the empire in the sixteenth century. In fact, the Ottomans supported a similar mass deportation of the nomadic tribal populations as we will see in our discussion of the Suleymani tribes. The central government re-organized 
the political administrative power structure in its north-eastern frontier and supported the Kurdish tribes and hereditary Kurdish Emirs all together.

This political shift transformed Kurdistan from a specifically ethnic denomination into more of a political-administrative structure. Baki Tezcan notes that until the sixteenth century, the region was not often known referred to as Kurdistan but rather as simply the region where Kurds lived. After this period, the region was predominantly referred to as Kurdistan and he believes that the term Kurdistan was therefore not based on ethnic considerations but rather a 'political-administrative arrangement'. ${ }^{2}$ We do not have detailed ethnic and demographic information of the region from the sixteenth century, so the question cannot be settled on the basis of ethnic arguments. However, Tezcan mentions that there was an explicit shift in the region though he does not describe the roles that Kurdish tribes took during this turmoil. This article contributes to the discussion of how Suleymani tribes became part of this significant shift in newly conquered lands of the Ottoman northeastern frontier. Mass migration of the Suleymani tribes into northerneastern Anatolia made the region more Kurdish with the support of the government in Constantinople.

This article first elaborates on the details of the Suleymani tribes and their traditional living spaces and structure. And then their migration to northern-eastern Kurdistan which was kept alive in the memory of tribes during the nineteenth century and fabricated by the tribes as part of a myth.

The most noteworthy details regarding the Suleymani tribes were given by Sharaf Khan. For him, Suleymani tribes consisted of eight separate ones: Besyan, Bociyan, Zilan, Zikziyan, Hevidi, Berazi, Dilhoran and Banuki. These tribes were ruled by the Suleymani Emirs during the sixteenth century and according to the Sharafnama, the region was Islamicized by the conquests of these tribes. ${ }^{3}$ The oldest reachable sources indicate that from the fifteenth century, Suleymani tribes controlled the eastern and northern regions of Diyarbekir: Meyyafarikin and Kulb. ${ }^{4}$ Ottoman land surveys noted that Suleymani tribes had wielded similar power in the same territories since Uzun Hasan had controlled the region during the mid-fifteenth century. ${ }^{5}$ Also, when the Safavids took over the region, the Emir of the Suleymani tribes, Mir Diyaeddin, allied himself with Muhammed Ustaclu, the governor of Diyarbekir. ${ }^{6}$ Though most of the Kurdish emirs were taken from power by the Safavids, the generalization that all Kurdish hereditary rulers were dismissed from power is an overestimation of the real political developments during the sixteenth century.

The Ottoman land surveys and mühimme registers present us with important details regarding the Suleymani emirs and tribes. As Tezcan indicates there were important clashes among the ruling class of Suleymani Emirs between Mir Diyaeddin and his nephews. ${ }^{7}$ Dynastic power struggles reduced the power of the ruling class, and the Ottoman central government used this struggle to divide and rule. Meyyafarikin (Silvan) was separated from Kulb and given to Behlül Bey. ${ }^{8}$ Meyyafarikin was an ordinary sanjak to Diyarbekir and Behlül Bey had to pay some taxes to the treasury of Diyarbekir Province. ${ }^{9}$ Suleymani emirs had to collect taxes from Suleymani tribes who often resisted paying them. This was another important reason why Suleymani emirs lost their power, since they were intermediaries between the central government and the powerful tribes, and they mostly failed to collect taxes from the tribes. A mühimme register clearly states that Behlül Bey was appointed as the emir of Besyan, Bociyan and Zilan tribes ${ }^{10}$ in return for 
collecting taxes from the tribes. He was threatened with the reassignment of his territories to another if he could not fulfill his duties. ${ }^{11}$ Therefore, we cannot ascribe the deterioration of powers of the Suleymani emirs solely to dynastic struggles, since central government was also important in the increased tension between Suleymani emirs and the tribes.

Another reason that caused the Suleymani emirs to lose their power was the relocation of the Suleymani tribes, especially at the northern Iranian frontier. The Sharafnama tells us that Behlül lost his life when he was trying to bring Suleymani tribes back to his territories. ${ }^{12}$ Some mühimme records show that Suleymani tribes did not follow the orders of Behlül Bey, and they allied with Yusuf Bey, the former governor of Ardahan. They even attacked Behlül Bey's houses and assassinated Behlül's brother, Elvend, along with his 30 of his men. ${ }^{13}$ For these reasons, the Suleymani emirs lost their political legitimacy in the eyes of their most important subjects, the Suleymani tribes. In sum, dynastic clashes were only one side of the coin, and as noted, there were a variety of reasons for the fluctuation in power of Kurdish dynastic rulers.

Although researchers often refer to the significance of the ruling elite of the hereditary Kurdish Emirs, the role of tribes is hardly mentioned. The Sharafnama describes the tribes as the main decision-makers in choosing their own leadership: 'After the death of Emir Celaleddin, since his son was a child, the chiefs of tribes and pioneers appointed Emir Izzeddin's brother, Emir Celaleddin, for their suzerain (hükümdar)...When Ibrahim reached adolescence; he became the ruler after confirmation by the tribes and clans. ${ }^{14}$ Behlül Bey is only one example of many - although the central government appointed him as the leader of the Suleymani tribes, the Suleymani emir, the tribes did not follow his orders and even decided to kill him and members of his family. ${ }^{15}$ Therefore, the main politicaladministrative structure was not based only on appointed hereditary rulers. Rather, it was also influenced by the tribes and tribal confederations wielding military power and engaged in economic activity at a local level. Ottoman documents indicate that if a hereditary family does not survive, the tribe and clans of the region nominated their own candidates, and tribes were part of this selection: 'Since the emirs of the sanjak of Bayezid, Muhammed II, and Suleyman were killed, the sanjak of Bayezid is leaderless...tribes and clans shall present their candidates by making an agreement among themselves.. ${ }^{16}$

Researchers also emphasize the military might of the Kurdish emirs when the Ottoman central government needed them in the struggle against the Iranian state. ${ }^{17}$ However, the military power of an emir actually came from the members of the nomadic tribal people. In a mühimme record, the central government ordered Zilan and another tribe of Suleymani tribes to be sent to the Sinjar region in order to protect the area which was controlled by 'bandits'. ${ }^{18}$ Legal surveys taken during the sixteenth century illustrate that Suleymani tribes were around 5000 households; this indicates that their numbers and population were significantly high. ${ }^{19}$ The central government even ordered Suleymani emirs to send Suleymani tribal warriors to the Battle of Lepanto in 1571 from Tripoli through Cyprus to Crete. However, only Shah Veled Bey, emir of the Suleymani Kurds in Kulb, sent 20 men from the Banuki Suleymani tribe. ${ }^{20}$ The other powerful Suleymani tribes of Besyan, Bociyan and Zilan refused to send men for this battle, and they were fined 10,000 Florentine gold florins ${ }^{21}$ for not sending their men. ${ }^{22}$ Behlül Bey was assigned to collect this money from his tribe and this assignment increased the tension between Suleymani Emir, Behlül Bey and the Suleymani tribes. The military might of the tribes was needed not only on the empire's eastern frontier but elsewhere too, and the orders of the 
central government were one of the main reasons for conflicts between the emir and the tribes. This conflict also reveals that the emirs actually received their military strength from below, from tribe members. In order to evaluate the importance of the tribes in the eastern frontier, it is worth recalling Evliya Çelebi's declaration on the tribes:

If six thousand Kurdish tribes and clans had not become a steady barrier between the Iraqi Arab and Ottoman lands, the Iranians would have invaded so easily. ${ }^{23}$

Evliya referred to a tribal barrier rather than to the emirs, since the tribes were the actual source of military strength. The Suleymani tribes were only one group among those Kurdish tribes that created a buffer/tribal zone between the two empires. However, we can call the region a marchland, too, since some Kurdish clans of the same tribal confederation sometimes pledged their loyalty to the Iranian shahs. ${ }^{24}$ Whether it was a buffer/tribal zone or a filter, ${ }^{25}$ the tribes were the most important elements on the Ottoman-Iranian frontiers by virtue of their movable military powers. Suleyman I described the political role of the Kurdistan region during the sixteenth century in similar terms:

God made Kurdistan act in the protection of my imperial kingdom like a strong barrier and an iron fortress against the sedition of the demon Gog of Persia. ${ }^{26}$

It is well known how Suleyman I created a buffer zone between his kingdom and the Iranian state. Selim I and Suleyman I legalized the local hereditary political-administrative rule of Kurdish emirs such as the Suleymani Emirs, Hakim of Bitlis, Hakkari and so on. However, previous researchers have missed how tribes were used in fortifying the barrier between the two empires. In this article, we suggest that Suleymani tribes were given support in being relocated to northern Ottoman Kurdistan. As Inalcik describes it, the Ottoman central government relocated the nomadic, movable Turcophone tribes of central Anatolia to the Balkans during the fifteenth century in a mass deportation to create a secure barrier in the western territories. ${ }^{27}$ This was a continuation of the Ottoman conquest to consolidate the existence of Ottoman administrative power on its frontier. Similar to the Balkans, parts of the Suleymani tribes were relocated to the northeastern Ottoman frontier. For the Sharafnama written in 1597, the Suleymani tribes moved to the newly conquered lands of the northern Kurdistan region in a promise to protect these territories against the Iranians. ${ }^{28}$ With this promise, the tribal chiefs of the Suleymani tribes were given the titles zeamet, sanjak beyi and alay beyi. Sharaf Khan mentions one chief among the Besyan tribal confederation, Shahsuvar Bey, who went to Bayezid province and declared its independence, and acme into conflict with its previous Suleymani emir, Behlül Bey. ${ }^{29}$ While the latter strove to protect his emirate by bringing the dispersed members of Suleymani tribes back to his territories to Meyyafarikin, Shahsuvar Bey headed some of those Suleymani tribes in building a new frontier emirate in Bayezid. We can confirm that Shahsuvar Bey controlled the province of Bayezid ${ }^{30}$ and that the Besyan chiefs became the rulers of the Bayezid sanjak as Katip Çelebi describes:

Bayezid is the frontier to the Iranians. The Diyadin and Hamur fortresses were ruled from Bayezid. Behlül Bey took the rule of this liva (sub-province) as an ocaklik (estate) for himself. They are Kurds of the Besyan tribe. Since they are so valiant, Iranians keep their distance from them. $^{31}$

Another Ottoman document also refers to the ruler of Bayezid as 'My servant Besyan Ishak Pasha'. ${ }^{32}$ Therefore, Sharaf Khan's data on giving new positions in the northern Ottoman- 
Iranian region seems correct according to these Ottoman documents. Major Trotter in his memorandum of 1880 confirms this idea that the memory of migration of tribes was protected during the nineteenth century too:

Edrisi (Idris-i Bidlisi) forced a great part of the nomad Kurds, 'who then, as now, preyed to a great extent upon the peaceable agricultural population and villages', to emigrate to the rich pastoral country in the neighbourhood of Erzeroum and Erivan. The Kurds thus transported were at the same time assured perpetual immunity from taxation conditionally on their acting as a militia for the protection of the Turkish frontier... In the reign of Monarchs further immigrations from the south appear to have taken place, and we now find Kurds scattered nearly all over the country, their northern limit being, roughly speaking, a line from Kars to Erzeroum, extended on to Divriki. It is said that, with the exception of the Kurds of Hakkiari, and the tribe of Mamakanlee, all the Kurds inhabiting the Erzeroum and Van districts originally came from the neighbourhood of Diarbekir. ${ }^{33}$

Ottoman mühimme records indicate that Suleymani tribes were actually familiar to the upper Kurdistan region since these territories were the summer quarters of the Suleymani tribes before their permanent relocation to the region. ${ }^{34}$ Sharaf Khan declares that, over the summer months, some Suleymani tribes were quartered in the summer pastures of the Aladağ Mountains. ${ }^{35}$ Their familiarity with this region became effective in making it their permanent wandering territory during the third quarter of the sixteenth century as the documents indicate:

Since their names mentioned tribes (Besyan and Zilan) that were located in the fortresses of Bidlis, Muş, Kefendur, Ahlat, Erciş and Adilcevaz, their assigned taxes cannot be paid by the stragglers remaining in Diyarbekir region. ${ }^{36}$

Since members of the tribes stayed in the castles, it might be seen as if they were assigned to the protection of the castles on the frontier as Sharaf Khan suggested. The tribes' military might let the Ottoman central government support their relocation to the northern Iranian frontier, but it did not mean that these Suleymani tribes always followed the orders of the central governments. In some mühimme records, the Suleymani tribes traded with the Iranians on the Ottoman frontier. They sold horses, goods and some commodities to what the documents literally describe as the 'upper side'. ${ }^{37}$ The central government tried to stop these relations since the role given to the tribes by the government was to protect the border and keep the Iranians away from the region. Nevertheless, the tribes pursued their own agendas for their own economic benefit.

As the Sharafnama describes, the Ottoman documents also confirm that the Suleymani tribes were given territories on the frontier of the Erzurum region:

In the frontiers of Erzurum, the ruined villages, which have fountains, masjids, and unclaimed buildings, are given to the chiefs of tribes in order to make the province well populated and prosperous. They will also make these places prosperous after coming to the region with their own followers. ${ }^{38}$

As Suleyman I's ideas indicated, the Ottoman central government wanted to build a safe zone against Safavid Iran and this safe zone was strengthened by relocating Suleymani tribes to the northeastern frontier. This policy was practiced over the tribes rather than emirs since, as we have seen, the tribes held military power. Therefore, the roles of tribes were as crucial as those of the allied emirs of Kurdistan in the politics of the region. 
The details given by Sharaf Khan on the migration of Suleymani tribes seem accurate, and Suleymani tribes did not disperse only toward the vicinity of Erzurum, Van and Kars but all around the region too. The Sharafnama mentions that Suleymani tribes were moved all around the region, and they attacked people around them in Muş, Hınıs and Malazgirt. ${ }^{39}$ A mühimme record gives us the details of these regions that Suleymani tribes dispersed to: Maraş, Karaman, Rum (Sivas), Mosul, Ahıska, Van, Diyarbekr, Erzurum and Kars. ${ }^{40}$ As Inalcik mentioned, the central government attempted to control these nomadic tribal movements by driving them toward the frontiers since their activities, especially against the settled population, was unwanted. ${ }^{41}$ In doing so, this feature of Suleymani tribes was seen as a problem by the central government. ${ }^{42}$

To sum up, the migration of the Suleymani tribe toward the northeastern frontier of the Erzurum, Van and Kars regions was supported by the central government since the tribes rather than the Kurdish emirs were the main source of military might in the region. Lands acquired from Safavid Iran were strengthened by relocating Kurdish tribes as can be seen in the example of the Suleymani tribes who were pushed toward the northern Iranian frontier to keep Iranians away from the newly conquered territories in the sixteenth century. Tezcan describes that there was a shift in which the region came to be called Kurdistan in a political-administrative structure though he does not describe the mass relocation of tribes toward the northern frontier. We will now move on to examining how the memory of the migration to the frontier was still vivid in the minds of the tribes of the northern Ottoman-Iranian borderland during the nineteenth century.

We can now discuss the perceptions of this migration by the descendants of the Suleymani tribes during the nineteenth century. During the nineteenth and early twentieth centuries, it is possible to detect that some tribes retained memories of their relocation to the northern Ottoman-Iranian frontier. When Mark Sykes visited the northern parts of Ottoman Kurdistan, which he categorized as 'section $\mathrm{D}$ ', he declared that a group of tribes in this region 'have been the masters of the country which they inhabit long before the government of Constantinople had any power there. ${ }^{43}$ Their tradition states that they originally came from Diarbekir'. ${ }^{44}$ The patronage of tribes in this region was not new and we can see that the tribes had been powerful and dominant entities on the northern Ottoman-Iranian frontier long before the Ottomans controlled the region. ${ }^{45}$ Based on the suggestion of Sykes, we can claim that not only were the emirs used as an instrument of expansion by the Ottomans, ${ }^{46}$ but also that tribes carried out the same aims on the Ottoman-Iranian frontier. The self-perception of tribes as having migrated from the Diyarbekir region indicates that the tribes did not forget their old traditional winter quarters. Sykes generalizes the 'traditional' perception of having migrated from the Diyarbekir region for only section $D$. This perception strengthened suggestions made above that Suleymani tribes relocated to the region with an important number of tribal populations though we do not know the exact numbers.

Hurshid Pasha and Dervish Pasha, who traveled across the Ottoman-Iranian borderland $^{47}$ in the mid-nineteenth century in order to demarcate the empires' borders with Russian, British and Iranian representatives, also mentioned that some powerful tribes of the northern frontier Serhad region had actually emigrated from the Diyarbekir region. ${ }^{48}$ Dervish Pasha says: 
According to what we learned from the experts of the region (erbab-ı vukuf), the tribes of Zilan, Şikak, Takori, Milan and Celali tribes were originally from the Diyarbekir region. ${ }^{49}$

His colleague, Hurshid Pasha, also made similar comments: 'According to the narratives of the experts of the (Van-Erzurum) region, the Zilan tribe was originally from Diyarbekir territory and immigrated to the provinces of Erzurum and Kars' and 'most of the tribes who wander around the sanjaks of Bayezid and Kars are Kurdish and ...in old times (kadimde) they came from the Diyarbekir region'. ${ }^{50}$ Both Ottoman representatives gave similar details about the previous living space of the tribes of the northern Ottoman-Iranian frontier. During this process of demarcation, referring to tribes as being from the Diyarbekir region actually meant that the tribes were Ottoman subjects rather than Iranian. Since the region was a borderland and the Ottoman and Iranian states argued about keeping the tribes on their sides, these two Ottoman bureaucrats needed to give this information. The Heyderan tribe ${ }^{51}$ was one those powerful tribal confederations in the region during nineteenth century, and both states claimed the 'Ottomanness' or 'Iranianness' of this tribe. ${ }^{52}$ However, this does not mean that the Ottoman bureaucrats fabricated the narrative of emigration from the Diyarbekir region. Hurshid Pasha's comment that most, if not all, came from Diyarbekir indicates that there were Kurdish tribes in the region that had not migrated and some tribes were more native to the northeastern Ottoman-Iranian frontier. Sykes also mentioned there were some tribes native to the region besides those that had migrated: 'These tribes I am inclined to look on as the original shepherd tribes of the region, who inhabited it before Class I entered the district'.$^{53}$ Beyond Suleymani tribes, there were other tribes too such as Milan and Shikak tribes who migrated from the Diyarbekir region. This article does not suggest that only the Suleymani tribes migrated to the Serhad region. Milan was a powerful tribe in lands from Mardin to Urfa region since the sixteenth century, ${ }^{54}$ and Shikak was mainly living under the Meliks of Hasankeyf regions as the Sharafnama and land surveys indicate. ${ }^{55}$ Both these regions were conceptualized as being part of Diyarbekir since the beglerbeyi, the representative of the Ottoman government, was in Diyarbekir and the tribes' lands were administratively subordinate to Diyarbekir. ${ }^{56}$ The Sharafnama and the mühimme records suggest that the Shikak and Milan tribes were not part of the Suleymani tribes and the Suleymani's living spaces were separate between Milan and Shikak. ${ }^{57}$ In sum, there was a perception of having migrated from the Diyarbekir region among the Kurdish tribes of the Serhad region during the nineteenth century.

The Heyderan tribe was one of those powerful tribes of the northern Ottoman-Iranian borderland during the nineteenth century, and Ottoman land survey records of 1540 show that they were a clan (oymak) under the Suleymani Zilan tribal confederation in the Meyyafarikin(Silvan) region. ${ }^{58}$ In some other records from the early nineteenth century, Mahmud Bey and Behlül Bey, the emirs of Bayezid who were the descendants of Suleymani and the son and grandson of, respectively, Ishak Pasha, referred to the Heyderan tribe as Silvani and Suleymani in two separate documents. ${ }^{59}$ The emir of Muş, Selim Pasha, also made a similar comment that Heyderan was originally from the Diyarbekir region. ${ }^{60}$ Hamidian Brigadier (Mirliva) Huseyin Pasha of Heyderan tribe also mentioned to Ali Emiri that their forefathers came from Meyyafarikin in the Diyarbekir region. ${ }^{61}$ Sykes described Heyderan as the most powerful tribal confederation in a marchland, extending from Erzurum and Van to the Iranian regions of Khoi and Maku in the late nineteenth century. ${ }^{62}$ 
Documents referring to the early period of the Heyderan tribe indicate the relocation of Suleymani tribes from the eastern parts of the Diyarbekir region, Meyyafarikin (now officially called Silvan) and its surroundings. Although Heyderan was originally a small Suleymani clan during the sixteenth century, it became the most powerful of its region in the nineteenth century; the ancient identity and conception of having migrated from Silvan were not forgotten by members of the tribe. An Ottoman document, written in 1822, also shows that not only Heyderan but other powerful tribes of northern Ottoman Kurdistan, the Zilan, Sepki, Cemedanli and Jalali tribes, were also called Silvani tribes. ${ }^{63}$ Hence, the perception of being relocated from Silvan was not specific only to the Heyderan tribe.

According to Vladimir Minorsky and some researchers along with local oral witnesses, the oldest name of their home, Meyyafarikin, was changed to Silivi or Silvani after the Suleymani Kurds. ${ }^{64}$ This shift shows that the tribes were at the center of transforming the region into Kurdistan. For Tezcan the use of the name Kurdistan for the region was not geographic and ethnic, but a political-administrative construct deliberately introduced by the Ottomans. ${ }^{65}$ He mentioned there was a shift in the region during the sixteenth century, but he does not talk about the main factor of the region such as the Suleymani tribes. As an example, the Suleymani tribes' names were equated with the region of Meyyafarikin during and after the sixteenth century and the terminology of being Silivi appeared among the Kurdish tribes. ${ }^{66}$ He does not talk about the population of the Kurds but suggests that the usage was not about the ethnic population. As mentioned above, during the mid-sixteenth century, the number of Suleymani households around Meyyafarikin was 5000, and this high number makes it logical for the name of the tribe to be equated with the city of Meyyafarikin.

There are also other - local - accounts of the connections between the nineteenth-century tribes of the northern Ottoman-Iranian borderland and the Silvan region. For example, Mela Mahmud-e Bayezidi, a nineteenth-century scholar from the city of Bayezid who wrote important books on the culture and traditions of the Kurds, ${ }^{67}$ suggests that Suleymani Kurds, whose original home was in Silvan and its surroundings, migrated to the northern Ottoman-Iranian frontier:

A man named Abdi Bey, who was originally from Meyyafarikin of Merwanids in Diyarbekir, entered the service of Sultan Murad IV together with some households from Silvan...The cities of Bayezid, Eleșkird, and Milwe along with their surroundings were given to Abdi Bey and the tribes of Silvan. These fortresses and villages were made prosperous by them. The name of the region of Bayezid and its sub-provinces became Silivanli (people who are from Silvan) because of the name of the tribes. ${ }^{68}$

Mela Bayezidi's view can be supported by Ottoman archives, which say that the emirs of Bayezid were referred as from the Suleymani Besyan tribe: 'Speaking to the Pasha of Erzurum Yeğen Ali Pasha and my Besyani servant, Ishak Pasha of Bayezid'. ${ }^{69}$ The grandson of Ishak Pasha, Behlül Pasha, who was the emir of Bayezid during the first half the nineteenth century, was also described by Persian sources as being from Silvan. ${ }^{70}$ As was described above, Katip Çelebi mentioned in the mid-seventeenth century that the ruler of Bayezid was Behlül Bey of the Besyan tribe. Ebdullah M. Varli confirms Mele Bayezidi's statement that Emir Abdi controlled the Bayezid region: 'the liva of Pasin was ruled by Abdi Bey, who was given the fortress of Bayezid as arpalik [a large estate given to the civil elites for tax-farming]. ${ }^{71}$ After the death of Abdi Bey, his son Behlül Bey, who was 
mentioned by Katip Çelebi, became the ruler of Bayezid, and another son of Abdi, Zayn ad-Din, became the ruler of Pasin in $1643 .{ }^{72}$ There was an important degree of relocating of the tribes and authorizing of them in newly conquered lands. Therefore, the use of the name Kurdistan was the result of symbiotic relations of the state-tribes, and in our case, it was the result of en masse demographic migration of the Suleymani tribes which had continued since the sixteenth century.

Although the underlying motive in his account in The Sociological Evaluation on the Kurdish Tribes was a statist perspective, Ziya Gökalp made important explanations parallel to our suggestions. Gökalp refers to a verse of Ahmedi Xani's poem 'Bokhti and Mameti and Silivi' but misinterprets Xani and believes that Xani named all Kurds speaking the Kurmanji dialect beyond Bohti and Mameti as Silivi. ${ }^{73}$ And Gökalp adds that the living places of all Kurmanjis can be called 'Silivan'. Gökalp did not make the connection between the migrated Suleymani tribes (Silivi tribes) of northern Ottoman Kurdistan and Meyyafarikin (Silvan), and he designated all Kurmanji speaking tribes as Silivani except the Bohti and Mameti. However, he realized that there was a dominant perception and appellation of being Silivani in the northern Ottoman-Iranian borderland. Ahmed-i Xani emphasized the name of the Suleymani tribes as Silivi as Mela Bayezidi did as 'Silivanli' by referring to the tribes of Suleymani Kurds, who migrated from Silvan (Meyyafarikin), and distinguished them from the other two, Bokhti and Mamedi (Mahmudi), which were different Kurdish emirates/tribes. While Bohti was powerful in Jazirat Ibn Omar, the latter ruled the eastern and southeastern spheres of Lake Van. ${ }^{74}$ However, Gökalp justly came up with the suggestion and says that Silivi was equal to the name of Zil(an), which meant the tribe of Suleymani Zilan. ${ }^{75}$ Gökalp also affirms that some members of the 'Silivi Kurmanji' speaking tribes did stay in their summer quarters in 'Van, Bidlis, Erzurum, Harput (currently Elazığ)' in old times although some stayed in their winter quarters. ${ }^{76} \mathrm{He}$ witnessed this during the First World War when northern Ottoman Kurdistan was occupied by Russian and Armenian military forces and the tribes of this region fled to their old traditional living places, the Diyarbekir region, and they were housed by members of the same tribes who had not migrated and had kept their collective identity alive. He even creates a terminology for the migrated members of the tribes as Gamiri or Gawesti, meaning 'the people whose oxen died or became exhausted' so that is why they could not return. ${ }^{77}$ This terminology, which was taken from the locals, does not currently exist, and symbolizes that the relocation of tribes on the northern edges of the Ottoman-Iranian frontier was an important shift in the minds of the locals too.

Gökalp also classifies the Kurdish tribes living between the basins of the Tigris and Kura Rivers under two supra-identities of Mil and Zil. For him, the Mils are the Kaskan, Cibran, Hasbat, Milan, Zirkan, Şadiyan, Suveydi and Cemaldiyan tribes; while the Zils are Jalali, Heyderan, Reman, Zilhan and Sipkan tribes. ${ }^{78}$ The leader of the Milli Tribe, Ibrahim Pasha, also made a similar classification of the Mil and Zil: 'Years and years ago, the Kurds were divided into two branches, the Milan and Zilan; there were 1200 tribes of the Milan, but God was displeased with them and they were scattered in all directions, some vanished, others remained; such as remained respect me as the head of the Milan. ${ }^{79}$ We will now discuss this classification which Gökalp and Sykes made, and show it to be a mythification of tribal identities.

If researchers dig into the perception of tribal identities in nineteenth-century Ottoman Kurdistan, they will swiftly realize that the Kurdish tribes of northern and central Ottoman 
Kurdistan, especially those living in northern Kurdistan, had a mythical narrative about their ancestral background. According to this myth, a father, named Kurd, had two sons, Mil and Zil, and all Kurdish tribes were actually descendants of these two brothers. ${ }^{80}$ This concept recalls the Japhetic mythical narrative that Japheth was the forefather of the Turkish race, and that Japheth's other two siblings, Shem and Ham, were the ancestors of Afro-Asiatic races. ${ }^{81}$ Similarly, the Kurdish tribes of the late nineteenth century adopted a similar narrative for their ancestral backgrounds and they excluded other ethnic-national identities and settled Kurds from this classification. These ethno-nationalist conceptions were created and absorbed by tribes of their own accord, and were not created by a topdown ethno-nationalist intelligentsia. One of the Sultan Abdulhamid II's aides-de-camp, Vehbi, mentions the following:

All Kurdish tribes consisted of two groups: Milan and Zilan. Likewise, they were called Mil and Zil by abbreviation. The Cibranlı, Hasenanli, and Heyderanli tribes are originally Milan tribes; and Sepki and Cemadanli, and likewise the Zilanli belong to the Zilan tribe. Arab and Arabized clans/tribes are excluded from this (classification). ${ }^{82}$

In 1893, Vehbi was charged with the important task of delivering the Hamidian Cavalry regiments' flags to the tribes most of which were Kurdish. His duties took him to most of Ottoman Kurdistan, and he reported this mythical narrative of Mil and Zil after his return to the capital. This extra information given by Vehbi is significant for two reasons. First, the story is a nationalist discourse because only the Kurds are included. Second, in this narrative, the Kurdish tribes attempted to establish one unique, general collective identity among themselves. Since the first aspect of the narrative is outside the scope of our consideration in this article, we leave it to further research. But the question of why tribes created a uniform collective identity during the late nineteenth century is actually not difficult to explain.

The Ottoman central government demolished the power of the local Kurdish dynasties during the mid-nineteenth century after several revolts broke out in the region against the centralization policies of the Ottoman government. ${ }^{83}$ The economic deficiency of the central government drew the Porte's attention to the assets of the local hereditary rulers who drew taxes from the territories that they ruled. Abdulmecid I used the appellation of conqueror of Kurdistan, and he minted medals that named Kurdistan as a sign of this significant shift in the history of the region. ${ }^{84}$ This transformation of the administrative structure created a power vacuum since the new policy of Tanzimat actually decentralized the regions' politics by eliminating the top elite class structure, the Kurdish emirs. After their elimination, tribal chiefs became the müdür or kaimakam of their own territories where their tribal members lived. ${ }^{85}$ Their titles were officially recognized by the state, and the central government plied the chiefs with ranks, medals and salaries. After Abdulhamid II inherited the throne, he organized light cavalry regiments among the Kurdish Sunni Ottoman tribes to suppress the Armenian nationalist revolutionaries and to control possible Kurdish movements in 1891. After the 1850s and the abolition of the powers of the emirs, Kurdish tribes now held great power that can be described as 'tribal re-emirization' ${ }^{86}$ In these circumstances, the tribes endeavored to create a political legitimacy to present themselves as the new re-emirized political top ruling class.

The distinctive and exclusive identity of the ruling class, the emirs, had created political legitimacy and exercise of power, ${ }^{87}$ and as the Sharafnama describes, almost all Kurdish 
emirs saw themselves as socially distinct from their people. ${ }^{88}$ When the tribes became the ultimate powers in the region during the reign of Abdulhamid II, they also made an attempt to create a distinctive identity in order to legitimize the power they exerted on seized territories. ${ }^{89}$ The Mil and Zil (Zil/Silivi) myth of tribes appeared during this shift. This primordial classification belongs to the late nineteenth century, as Bozkurt confirms: 'AlBaladhuri, Ibn Al-Athir, Ibn Hawkal, Qalqashendi, Al-Muqaddasi, Al-Marqazi and Al-Omari, such writers and geographers, did not mention this classification'. ${ }^{90}$ Non-tribal settled Kurds, designated as reaya or yerli (indigenous) by the tribes, were not be included to this collective identity since, as Major Trotter mentions in his memorandum, they were subordinate to the tribal Kurds who were a 'superior race'. ${ }^{91}$ In a way similar to their previous ancien régime hereditary rulers, the tribes now created their own collective identity when they saw their own future as possible emirs of their own territory. The mythification of tribal power appeared during the late nineteenth century, and it was the product of symbiotic mutually empowering state-tribe relations.

Although the old-fashioned typology of anthropological and historical research refuses to admit that the state-tribe relation was always one of conflict, some research has indicated that the state and the tribes mostly co-existed and supported each other and had symbiotic relations. ${ }^{92}$ Tribes might produce their own myths, and states as well, in order to force their constituents into the same collective identity. ${ }^{93}$ Therefore, the mythification of tribal collective identity, Mil and Zil, was the by-product of state support for the tribes after the empowerment of the tribes by Abdulhamid II's new policies as the tribes needed to create a political legitimacy in Ottoman Kurdistan's new administrative structure.

Now, we can ask why this tribal Kurdish myth was shaped around the names of Mil and Zil only. This classification actually indicates an ancient geographical division ${ }^{94}$ and historically separate identity between the two powerful tribes: Milli and Suleymani Zilan. During the sixteenth century, when there was an important shift in the history of the region, Milan's geographic living space was in basin between the Mardin and Urfa provinces, while Zilan was part of the Suleymani Kurds in the eastern territories of Diyarbekir and Meyyafarikin and their surroundings. ${ }^{95}$ These two tribes controlled separate territories and they had separate tribal identities since the sixteenth century. During the nineteenth century, the Milli tribe was still overwhelmingly living in the same territories while Zilan (Silivi) was living in the marchland of the borders of the Ottoman, Iranian and Russian territories. Their ancient divisiveness became geographically more distinct when the myth appeared during the late nineteenth century, since Zil/Silivi/Suleymani tribes were overwhelmingly living in the northern Ottoman-Iranian borderland. It is possible to see this distinction of identity between Milan and Zilan tribes in some local traditional folk songs (dengbej), such as Şakiro's songs, which describe the conflicts between the two groups. ${ }^{96}$

As mentioned above, some tribes of the northern Ottoman-Iranian region still preserved a memory of their ancient living spaces and of being from the Silvani/Suleymani Tribe. Therefore, we can suggest that these historic separate identities were alive in the memory of the tribes together with geographic divisiveness between the two. The conception of being Silivi/Silvani or being from Suleymani Kurds allowed tribes of the frontier to keep the name of Zili/Zilan/Silivi. Therefore, we can assert that mythification of tribal identities was partly the result of migration of Suleymani tribes, which kept the identity of tribes active and separate from Milan. Suleymani tribes like the Besyan Tribe in Bayezid and Pasin had been given important administrative powers in the northern Ottoman 
Kurdistan region and some Suleymani clans, such as Heyderan, became patrons of the region, as Sykes mentioned. When Abdulhamid II plied Huseyin and Ibrahim Pashas with the top titles and status among 65 Hamidian regiments, this increased the sense of divisiveness between Mil and Zil groups, since the latter was the leader of the Milli Tribe and the former was associated with the leadership of Zil/Silivi. This political-administrative dominance and demographic control of the rural region of the northern Ottoman-Iranian frontier by Suleymani tribes was an important reason why the identity of Zil/Silivi was chosen as a supra-identity in the region.

Although the brothers Zil's and Mil's father, Kurd, never existed, the tribes created their own supra-identities because of developments in Ottoman Kurdistan. The migration of Suleymani tribes to northern Ottoman Kurdistan started from the third quarter of the sixteenth century, the elimination of ancien régime Kurdish Emirs during the second quarter of the nineteenth century, and the empowering of tribal chiefs under Hamidian regimes were the three main reasons for the appearance of the myth of Mil and Zil during the late nineteenth century. This tribal myth was the outcome of important shifts in the region during the sixteenth and late nineteenth centuries. Hence, the fictional narrative of Mil and Zil brothers has something of real significance to tell us.

\section{Conclusion}

Similar to the Ottoman western expansion in the Balkans during the fifteenth century, the central government used the relocation of nomads to fortify its conquests on the northern Iranian frontier during the sixteenth century. Though it is not possible to estimate the size of the population that migrated, Suleymani tribes settled in their summer quarters after the third quarter of the sixteenth century. Chiefs of the emigrated tribes were given administrative-political status in newly conquered regions, and there was a demographic en masse movement toward the northern Ottoman-Iranian borderlands. Therefore, Tezcan's idea that the usage of the term Kurdistan after the sixteenth century was only administrative-political was legitimate. However, it is deficient since he omitted the demographic movement of tribes toward the northern Ottoman-Iranian frontiers. This shift enhanced the usage of the name of Kurdistan in this territorial region, and therefore, we can assert that tribes played a major role in these movements and the usage of the name of Kurdistan was also based on geography and ethnic composition. Although the roles of Kurdish emirs have been thoroughly discussed by previous researchers, this article has attempted to illustrate that tribes played major roles because of their political and military powers. Tribe-state relations were dynamic, and this article shows that the state supported, and even fostered, the creation of an emirate by supporting chiefs of the tribes, as we saw in the case of Besyan.

The memory of migrations was kept alive in the mind of nineteenth-century Kurdish tribes at the local level, and tribes preserved the knowledge of their ancient living spaces. A sixteenth-century clan, the Heyderan, became one of the patrons of the northern Ottoman-Iranian borderland, while the most powerful tribal agent of the Besyan confederacy lost its tribal identity and shrank to a small clan. However, the chiefs of the Besyan tribe became the rulers of Bayezid region. Hence, there was a vice versa transformation of creation and dissolution of tribes between the time spheres of the sixteenth to the nineteenth 
century. However, there were still some tribes, such as the Zilan and Milan tribes, that kept their identities alive and powerful from the sixteenth century,

After the suppression of hereditary Kurdish rulers during the third quarter of the nineteenth century, tribal chiefs attempted to increase their political legitimacy as previous Kurdish dynasts had, and during the late nineteenth century, we see the creation of a myth of Kurdish brothers Mil and Zil. The ancient tribal identities of Milan and Zilan were chosen for this categorization since they had become more geographically distinct from each other during the nineteenth century because of the migration of Suleymani tribes to northern Ottoman Kurdistan. Zil or Zilan were sometimes referred as Silvani/Silivani, since it was a reference to their ancient identity of Suleymani tribes. Therefore, most of the tribes that migrated to northern Ottoman Kurdistan saw themselves as on the Silivi/Zil side during the nineteenth century.

\section{Acknowledgments}

I am indebted to Oktay Özel and Metin Atmaca for their comments and also to Patrick Taylor and Adnan Demir for editing this article.

\section{Disclosure statement}

No potential conflict of interest was reported by the author.

\section{ORCID}

Erdal Çiftçi http://orcid.org/0000-0002-8716-2031

\section{Notes}

1. H. Inalcık, 'Ottoman Methods of Conquest', Studia Islamica No.2 (1954), p.122.

2. B. Tezcan, 'The Development of the Use of "Kurdistan" as a Geographical Description and the Incorporation of this Region into the Ottoman Empire in the Sixteenth Century', in The Great Ottoman - Turkish Civilization, eds. Kemal Çiçek et al. (Ankara: Yeni Türkiye, 2000), Vol.3, pp.54053.

3. For Sharaf Khan, Suleymanis were living in Meyyafarikin and Kulb regions from when the Merwanids ruled. We leave the discussion of previous centuries for different research. Ş. Han, Şerefname: Kürt Tarihi (Istanbul: Nubihar, 2003), pp.301-10.

4. E. Bekr-i Tihrani, Kitab-ı Diyarbekriyye, tr. Mürsel Öztürk (Ankara: TTK, 2014), pp.34, 45, 221. Y. Baluken, 'Hasankeyf Eyyubileri' (Hasankeyf Ayyubids) (630-866/1232-1462) (PhD thesis, Erzurum University, 2016), p.181. Baluken mostly refers to an important chronicle, Ibn Munshi al-Hısnî's Nuzhetun'n-Nazır.

5. M. Ilhan, Amid (Diyabakır): 1518 Detailed Register (Ankara: TTK, 2000), pp.153,172. 'Hasıl-ı işan beruce maktuu an kadim der zaman-ı Hasan Padişah hemçun bude'.

6. Ş. Han, Şerefname, pp.303-4; Tezcan, 'The Development', pp.548-9.

7. Tezcan, 'The Development', pp.548-9.

8. Ş. Han, Şerefname, pp.307-9; Tezcan, 'The Development', pp.548-9 S. Çelik, '21 numaralı Mühimme Defteri' (Unpublished MA thesis, University of Istanbul, Istanbul, 1997), no page numbers, nr: 153.

9. A. Atlı, '22 Numaralı Mühimme Defteri'nin Transkripsiyon ve Değerlendirilmesi' (Unpublished MA thesis, University of Erciyes, Kayseri, 2013), p.51. 
10. Mühimme records mentioned Suleymani Emirs as Ulus Beyi, Besyan Beyi or Besyan, Bociyan, Zilan Beyi.

11. S. Çelik, '21 numaralı mühimme', nr: 153: 'Vusul bulduk da bir an ve bir saat tehir u aram eyleyip eğer simdiye dek teslim olunmamış bi kusur 10 bin filori cem u tahsil edip dahi hızaneyi amireme teslim eyleyesin söyleki teslim itmeyip avk olına dirliğin alınmağla konılmayıp hakkından gelinir ana göre tedarik eyleyesin'.

12. Ş. Han, Şerefname, p.308.

13. M.A. Ünal, Mühimme Defteri 44 (Izmir: Akademik Kitabevi, 1995), p.72.

14. Ş. Han, Şerefname, pp.303, 305: 'Ali Firi named chief of Besyan tribe invited disinherited Suleymani Emir, Şah Veled Bey, to return from Damascus and rule Suleymani tribe'.

15. M.A. Ünal, Mühimme Defteri 44, p.72; Ş. Han, Șerefname, p.308.

16. E.M. Varli, Diwan u Jinewari ya Ahmed e Xani (Istanbul: Sipan, 2004), p.348: 'Begleri Muhammed-i Sani ve Süleymani katl olunduğundan, livay-i mezbur begsiz ve kimsesiz kalmakla...cumhur-u aşair ve kabail bi ittifak...itibarınız kimdir tarafımıza arz ve i'lam eyleyesiz-1117(1705)'.

17. Tezcan, 'The Development', p.545. D. McDowal, A Modern History of the Kurds (London: IB Tauris, 2005), pp.21-36; H. Ozoglu, Kurdish Notables and the Ottoman State: Evolving Identities, Competing Loyalties, and Shifting Boundaries (New York: Suny Press, 2004). M. Van Bruinessen, Agha, Shaikh and State (London: Zed Books, 1992), pp.136-75.

18. R. Şahin, '22 numaralı Mühimme Defterinin Transkripsiyon ve Değerlendirilmesi' (Unpublished MA thesis, University of Erciyes, Kayseri, 2014). pp.109-10. The same orders were given during the protection of the Basra region against the attacks by Arab tribes. And the central government ordered Kurdish Emirs to send tribal powers to Basra: Suleymani Alican Bey of Kulb and Emir of Besyan-Bociyan-Zilan (no name) were some of those names assigned for this duty. 5 Numaralı Mühimme Defteri (973/1565-1566) Özet ve Indeks (Ankara: Devlet Arşivleri Genel Müdürlüğü, 1994), p.166. Mühimme Registers have plenty of records of the military might of the Suleymani tribes used by the Ottoman central government during the sixteenth century.

19. Y. Halaçoğlu, Anadolu'da Aşiretler, Cemaatler, Oymaklar (1453-1650) (Ankara: Togan, 2011). According to Halacoğlu's records based on the Tax Register of 1568, the total number of Suleymani households was 5158. The bachelor (mücerred) number was 1457. If we estimate every household had an average of five persons, the total population reaches 28,000 .

20. 12 Numaralı Mühimme Defteri (978-979/1570-1572) (Ankara: Devlet Arşivleri Genel Müdürlügü, 1996), Vol.2, p.197. Central government found this number low for Suleymani tribes in the Kulb region.

21. The florin was a gold coin minted in Europe and used by the Ottomans, sometimes as a taxation measurement, as resm-i flori. Halil inalcik, 'Filori' in DiA, Vol.13, p.106.

22. 12 Numaralı Mühimme Defteri, p.359: 'Biz piyâde virmeğe kâdir değilüz; perâkende olup ısyân u tuğyân iderüz' 12/528: 'Piyâde vü kavvâs virmeğe kudretimüz yokdur. Ammâ; on bin filori yaylakdan avdet olundukda virelüm', p.223: Later the beglerbeyi of Diyarbekir requested central government to reduce to 3000 filoris and it was accepted.

23. E. Çelebi, Seyahatname (Istanbul: Yapı Kredi, 2006), Vol.iv, p.110: 'Irak-ı Arap ile Osmanoğlu arasında bu yüksek dağlar içinde 6.000 adet Kürt aşiret ve kabileleri sağlam bir engel olmasa Acem kavmi Osmanlı diyarına istila etmeleri çok kolay olurdu'.

24. A clan of te Suleymani tribe, Bayındır Bey of the Besyan tribe, crossed to the Ottoman side together with other tribes, and they were settled in Adana province: Murat Alanoğlu, ' 86 Numaralı Mühimme Defteri'nin Özetli Transkripsiyonu ve Değerlendirilmesi' (Unpublished MA thesis, University of Erzurum, Erzurum, 2010), pp.105-6.

25. Sabri Ateş sees the Ottoman-Iranian borders not as a zone but as a filter since there was a combination of not only orders of state but also local resistance of borderlanders. S. Ateş, The Ottoman-Iranian Borderlands: Making a Boundary 1843-1914 (New York, Cambridge, 2013), p.319.

26. Tezcan, 'The development', p.546. R. Murphey (ed. and tr.), Kanun-name-i Sultani li Aziz Efendi (Aziz Efendi's Book of Sultanic Laws and Regulations: An Agenda for Reform by a Seventeenth Century Ottoman Statesman) (Harvard: Harvard University Press, 1985), p.35: 'Fitne-i Acem def'ine Kürdistan'ı bir sedd-i sedid ve hisar-ı hadid eylemiştir'.

27. Inalcık, 'Ottoman methods of Conquest', pp.122-9. 
28. Ş. Han, Şerefname, p.308.

29. Ş. Han, Şerefname, p.308. According to an Ottoman record, Bayezid sanjak was given to Shahsuvar Bey in 1585: BOA, Kamil Kepeci 262/101(thanks to Hakan Kaya for sharing this document with me).

30. Based on an Ottoman record, Bayezid was given to Shahsuvar Bey in 1585: BOA, Kamil Kepeci, 262/101.

31. K. Çelebi, Cihannüma (Istanbul: Istanbul Büyükşehir Belediyesi, 2010), p.514: 'Bayezid Acem ile huduttur. Diyadin ve Hamur kaleleri de buna tabidir. Bu livayı Behlül Bey ocaklık olarak almıştır. Bunlar da Besyan aşiretinden olan Kürtlerdir. Gayet yiğit olduklarından Kızılbaşlar bunlardan çekinirler'.

32. Varl, Diwan u Jinewari, p.317. However, Varlı believes that not only the Besyan tribe but also sometimes Dunbuli and Mahmudi Kurdish Emirs controlled Bayezid: 'Le bi purani serweri di deste hoza Bazoki u Bisyani u Mahmudi u Dunbuli da buye'. Kırzıoğlu confirms this: '(Bayezid) Kal'a Hakimi olan Emir Beğ Mahmudi' Fahrettin Kırzıoğlu, Osmanlılar'ın Kafkas-Ellerini Fethi (Ankara: TTK, 1998), p.138.

33. FO 424/107(1880).

34. 7 Nolu Mühimme Defteri (975-976/ 1567-1569) (Ankara: Devlet Arşivleri Genel Müdürlüğü, 2014), p.95-6. I do not mean that migrated tribes were settled there.

35. S. Han, Serefname, p.303: Sharaf Khan asserts that there were hundreds of groups of Suleymani tribes who pastured their sheep in the highlands of the Bidlis, Şerafeddin and Aladağ Mountains from the spring season to autumn and they paid 1 in 300 sheeps $(1 / 300)$.

36. 91 Numaralı Mühimme Defteri (H. 1056/M.1646-1647) (Istanbul: Devlet Arşivleri Genel Müdürlüğü, 2015), pp.235-6: 'Aşayir-i mezburdan beher sene Bitlis ve Muş ve Kefendür ve Ahlat ve Erciş ve Adilcevaz kaleleri neferatına tayin olunan beş buçuk yük akçayı verirler iken hala aşairi mezburun ekseri varip zikrolunan kalelerde tavattun edip'.

37. 'Yukarı canib': In Two Separate Years, 1568 and 1574, the Ottoman Central Government Mentioned the Same Problem of Tribes' trade to the Iranian side: 7 Nolu Mühimme Defteri, pp. 95-6, and BOA, A. \{DVNSMHM.d 26/946.

38. 7 Nolu Mühimme Defteri, pp.95-6: 'vilâyet-i Erzurum serhadlerinde mescid ü çeșme ve gayriden eser-i binâ ve makâbir olan kadîmî harâbe karyeleri vilâyet-i mezbûre ma'mûr olaldan berü beğlerbeğiler emr ile şeneltmek tarîkı üzre aşîret sâhıblerine tîmâr virüp anlar dahı ehl [ü] ıyâl ve tevâbi'ları ile varup ma'mûr idüp'.

39. Ş. Han, Şerefname, p.309.

40. 91 Numaralı Mühimme Defteri, pp.234-5.

41. Inalcık, 'Ottoman Methods of Conquest', pp.122-9.

42. Ottoman Mühimme records confirm Sharaf Khan that Suleymani tribes attacked some settled populations in the Muş region in 1567. Two Suleymani Emirs, Emir of Besyan-Bociyan-Zilan tribes, Halid Beg; and Emir of Banuki Tribe-and Kulb, Alican Beg, were warned by the central government: 'If you do not help to bring your tribe under order and if you neglect and protect them, you must know that the tyranny of one of your tribes will make you responsible', 'aşîretünden biri fesâd idüp elegetürmeğe sen mu'âvenet itmeyüp ihmâl eyleyüp hımâyet eyleyesin, mes'ûl olursın; bilmiş olasın': 7 Nolu Mühimme Defteri, p.273.

43. We should think that the Ottoman central government became powerful there after the elimination of emirs.

44. M. Sykes, 'The Kurdish Tribes of the Ottoman Empire', The Journal of the Royal Anthropological Institute of Great Britain and Ireland Vol.38 (Jul.-Dec. 1908), pp.475-8. Sykes classifies northern Ottoman Kurdistan into four classes. He made the above-mentioned comments for the tribes of class I (Hasenan, Berizan, Cibran, Sipkan, Ziriki, Rișvan, Zilan, Heyderan, Ademan). For him, tribes of class II (Mamakan, Badeli, Şaderli, Torini, Aliki) were more native to the region since they 'inhabited it before Class I entered the district'. Some tribes of class I (Cibran and Sipkan) have ruled the tribes of class II (Aliki, Şaderli, Mamakanli). While the tribes of class III, Sheikh Bezeini and Isoli, were exiled to the region by Selim I, he confesses that he has no knowledge of the tribes of class IV, Besyan and Yezidis. The Besyan tribe was one of the mother Suleymani tribes after the sixteenth century, and for Sykes's data, Besyan lost its power as a tribe which only left 
70 households. We should keep in mind that the emirs of Bayezid were the leaders of Besyan tribe. We might suggest that Besyan transformed into an identity of emirate, its tribal members separated, and some members of Besyan tribe stayed as a small tribe. Sykes did not know that the Besyan was an ancient powerful tribal confederation. Class I consisted of Suleymani tribes such as Zilan, Heyderan, Berizan and Ademan.

45. Emphasis of Sykes, 'Ottoman control in the region', can be seen as the time of the midnineteenth century when the Ottoman central government eliminated local hereditary rulers and controlled region directly. M. Eppel, 'The Demise of the Kurdish Emirates: The Impact of Ottoman Reforms and International Relations on Kurdistan during the First Half of the Nineteenth Century' Middle Eastern Studies Vol.44, No.2 (March 2008), pp.237-58.

46. T. Sinclair, 'The Ottoman Arrangements for the Tribal Principalities of the Lake Van Region of the Sixteenth Century', in Ottoman Borderlands: Issues, Personalities and Political Changes, eds. K. Karpat and R. Zens (Madison: University of Wisconsin Press, 2003), pp.119-43.

47. I believe that Ottoman Kurdistan was transformed from a frontier to a borderland when the Porte began to directly rule the region after the elimination of the Kurdish hereditary rulers during the second quarter of the nineteenth century. J. Adelman and S. Aron, 'From Borderlands to Borders: Empires, Nation-states, and the Peoples in between in North American History', The American Historical Review Vol.104, No.3 (Jun. 1999), pp.814-41. Check Michael Eppel's article.

48. Diyarbekir was a big beglerbeyilik province in the region and what is referred to here as Diyarbekir does not mean the city center of Amid which was the central city of Diyarbekir province.

49. D. Paşa, Tahdid-i Hudud-u Iraniye (Istanbul: Matbaa-i Amire, 1870), p.162: 'Bazı erbab-ı vukufdan istihbar olunduğuna nazaran' aldığı bilgilere göre Zilan, Şikaki, Takori Milan ve Celali gibi Serhad bölgesindeki önde gelen güçlü aşiretlerin kökeni Diyarbekir bölgesine dayanmaktadır.'

50. M.H. Paşa, Seyahatname-i Hudud, tr. Alaattin Eser (Istanbul: Simurg, 1997), pp.265-66: 'Ehl-i vukuftan birinin rivayetine göre işbu Zilanlu aşireti an asıl diyarbekir taraflarından Erzurum ve Kars eyaletlerine' gelmiş olduğunu vurgular ve 'Bayezid ve Kars sancaklarıla civarlarında bulundukları zikr olunan aşairin kaffesi Ekrad olup...kadimde Diyarbekir tarafından bu havaliye gelmiş'.

51. See endnotes $56-58$.

52. Both States claimed that the Heyderan tribes were their own subjects: BOA, Hat 4/108- (1820): 'Haydaranlu ili ki ikiyüz seneden beri Iran elatidir - (Heyderan has been an Iranian tribe for two hundred years)'. BOA, Hat 812/37250U- (1826): 'Asıl Devlet-i Aliye-i Osmaniye'nin Aşair-i Ekradı'ndan olan Sepkili ve Heyderanlu aşiretleri (Sepki and Heyderan tribes are originally from the Kurdish tribes of Ottoman Empire).'

53. Sykes, 'The Kurdish Tribes of the Ottoman Empire', p.476.

54. M.R. Ekinci, 'Osmanlı Devleti Dönemi'nde Milli Așireti 18.-19.yy' (Unpublished PhD thesis, University of Fırat, Elaziğ, 2017). Y. Halaçoğlu, Anadolu'da Așiretler, Cemaatler, Oymaklar (14531650) (Ankara: Togan, 2011).

55. Halacoglu, ibid. Şeref Han, Şerefname, p.196.

56. The Ottoman central government administratively ruled the region from the center of Diyarbekir, Amid. Hasankeyf (Hısn-ı Keyfa), Ruha (Urfa), Siverek, were some of those sub-provinces of Diyarbekir vilayet/eyalet during the sixteenth century. In a defter (registry book) written in 1520 , there was a province of 'Liva-i Suleymaniyan (province of Suleymanis) ruled by Şah Veled Suleymani (who joined the war in Koçhisar, Mardin against the Safavids)'. Nejad Göyünç, 'Diyarbekir Beylerbeyiliği'nin Ilk idari Taksimatı', İstanbul Universitesi Tarih Dergisi (23/ 1969), p.28. After 1578, we confront an administrative division of Diyarbekir, 'aşiret-i Besyan', which was separated from Kulb, where it was ruled as yurtluk. After 1609, Meyyafarikin appears instead of 'aşiret-i Besyan'. In the eighteenth century, Meyyafarikin became a suzerain sub-province as hükümet while Kulb became an ordinary Ottoman province. Ibrahim Yılmazçelik, 'XVIII. yüzyıl ile XIX. Yüzyılın ilk yarısında Diyarbakır Eyaletinin Idari Yapısı ve Idari Teşkilatlanması' Tarih Araştırmaları Dergisi (29/ 1997), pp.217-32.

57. Mühimme records and land surveys of the sixteenth century can be investigated for this claim. This article does not suggest all Kurdish tribes of northern Ottoman Kurdistan were the 
Suleymani tribes but asserts that most of them were part of migrated Suleymani tribes. Halacoglu, ibid. S.. Han, Şerefname, p.196.

58. BOA, TD 200, p.455: land survey of 1540 indicates 31 households of Heyderan and referred to them as 'Oymak-ı Heyderanlı tabii Zilan (the Clan of Heyderan part of Zilan)'.

59. Heyderan was also a Silvani/Suleymani tribe according to the Ottoman records: BOA, C.ML. 562/ 23066-(1809): Mahmut Pasha says 'Süleymani aşairinden Heyderanlu aşireti (One of the Suleymani Tribes: Heyderanlu)'. BOA, HAT 825/37413 H (1820): Behlül Pasha mentions '... așair-i silivani Haydaranlu aşiretinin ağası kasım ağa... (Tribe of Silivani, chief of Heyderanlu tribe Kasım Agha)'.

60. Selim Pasha, sanjak begi of Muş, mentioned that according to the elders of the Heyderan tribe, they were originally from Meyyafarikin and they had lands there before they migrated to Muss region: BOA, HAT 1/18K-(1820).

61. A. Emiri, Osmanlı Vilayat-ı Şarkiyesi, Istanbul, 1337(1918), p.53: '...Bu tarih(kitabı) Erzurum havalisine ait olmayıp Diyarbekir ve Meyyafarikin'e ait olduğu ve ecdadı Diyarbakır tarafından Erzurum canibine geldikleri vakit birlikte getirdiklerini... (This history book does not describe the Erzurum region but Diyarbekir and Meyyafarikin, and his (Hüseyin Pasha's) forefathers brought the book when they arrived in the Erzurum region)'. J. Klein, The Margins of Empire: Kurdish Militia in the Ottoman Tribal Zone (Stanford, CA: Stanford University Press, 2011), chapters 3-4. T. Abak, Kürt Politikasında Hamidiye Siyasetine Dönüş ve Kör Hüseyin Paşa Olayı, 1910-1911 in 1915: Siyaset, Tehcir, Soykırım, eds. F. Adanır and O. Özel (Istanbul, Tarhi Vakfı Yurt, 2015), p.277-93.

62. Sykes, 'The Kurdish Tribes of the Ottoman Empire', p.478.

63. BOA, HAT 811/37227-1822.

64. V. Minorsky, 'Meyyafarikin' in IA, Vol. 8, Istanbul 1980, p.200.

65. Tezcan, 'The Development', p.540-53.

66. Minorsky, 'Meyyafarikin', p.200: For Minorsky, 'The Old Name of Meyyafarikin was Changed to Silvan (Silvani Before) Which is Nothing More Than the Name of Suleymani/Slevani. Fahrettin Kırzıoglu', Dağıstan-Aras-Dicle-Altay ve Türkistan Türk Boylarından Kürtler (Ankara: Türk Kültürünü Araştırma Enstitüsü, 1984), p.33. For Kırzıoglu Zilan tribe gave its name to Silvan. Silvan was a kaza (sub-district to Diyarbekir) after 1846. BOA, HAT 790/36808 (1846). Hazro and Kulb were ruled from Silvan as Suleymani Kurds controlled this territory during the sixteenth century.

67. M.M. Bayezidi, Adat u Rüsumatnamee Ekradiye (Istanbul: Nubihar, 2012).

68. R. Alakom, Torin: Aristokraten Serhede (Istanbul: Avesta, 2009), p.29: 'Miroveki bi nave Evdi Beg bi asle xwe ji Merwaniyen Mayafariqine buye, ji Diyarbekire, digel çend malbaten Silivan hatiye tevi xizmeta Sultan Murat buye....bajaren Bazide, Eleşkirte, Milwe u hawirdoren wan yurtluk ocaklık xelati Evdi Beg u ela Silivan kiriye. Wan li wir qela u gund avakirine, li wir mane u nave Bazide u qezayen we buye 'Silivanli' ser nave ele.'

69. Varl, Diwan u Jinewari ya Ahmed e Xani, pp. 353: Varli referred to BOA, C Dah. (1 Ramazan 11901776): 'Erzurum Pașası Yeğen Ali Pașa'ya hitaben ve Bisyani kullarım Ishak Pașa'ya hitaben'.

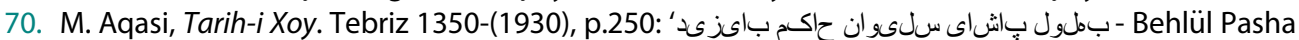
of Silvan the ruler of Bayezid'. Varlı, Diwan u Jinewari ya Ahmed e Xani, p.352.

71. Varlı, Diwan u Jinewari ya Ahmed e Xani, p.346: 'Livay-i Pasin der tasarruf-u Abdi Bey, hakim-i Kaley-i Bayezid ber vech-i arpalık 1040-1640'.

72. Varlı, Diwan u Jinewari ya Ahmed e Xani, p.346: 'Begzade Abdi Bey fi 17 Muharrem 1053-1643 fevt kılınmak ile Erzurum mutasarrıfı vezir Siyavuș Paşa arzı mucibince oğlu Behlül Bey hakim-i Kaley-i Bayezid terfine, diğer oğlu Zeyneddin Bey der Pasin bekasına'. Some researchers deliberately distort the suggestion that the Emirs of Bayezid were from the Suleymani Besyan tribe, and they believe that the emirs of Bayezid were from Çıldır region in order to Turkify the rulers of Bayezid. S. Eyice, 'İshak Paşa Sarayı', Diyanet Islam Ansiklopedisi Vol.22, pp.542-4.

73. Z. Gökalp, Kürt Aşiretleri Hakkında Sosyolojik Tetkikler (Istanbul: Kaynak, 2011), p.35.

74. Şeref Han, Șerefname, pp.165-88 and 336-43.

75. Gökalp, Kürt Așiretleri, p.35.

76. Gökalp, Kürt Aşiretleri, p.36. 
77. Gökalp, Kürt Așiretleri, p.36. Celadet Ali Bedirhan also shares similar idea that Gawesti tribes: Herekol Azizan (Celadet Ali Bedirhan), 'Mil u Zil: Bir u Esasen Eşiren Kurdan' in Ronahi: Supplement Illustre De La Revue Kurde Hawar (issue 11/ 1 Feb. 1943), pp.12-4.

78. Gökalp, Kürt Aşiretleri, p.96.

79. Sykes, 'The Kurdish Tribes of the Ottoman Empire', p.470. Şerif Fırat, a local writer, also made a similar comment that there was a division between Milan and Zilan. The head of the former was Milli Ibrahim Pasha and the latter was Mirliva Huseyin Pasha of the Heyderan Tribe. Şerif Fırat, Doğu Illeri ve Varto Tarihi (Istanbul: Yayın B, 2013), p.150. Fırat conceptualized the Kurdish nationalist movements of Sheikh Said (1925) and Ararat (1927-1932) with this supra-identity of Milan and Zilan. For him, while the former was a Milan, another was a Zilan movement. Firat, Doğu Illeri, p.19.

80. C.A. Bedirhan shares what he heard from a local uneducated man, the story of a man named Kurd and his two sons, Mil and Zil: Herekol Azizan (Celadet Ali Bedirhan), 'Mil u Zil', pp.12-4.

81. B. Ögel, Türk Mitolojisi (Ankara: TTK, 1989). Ibrahim Kafesoğlu, Türk Milli Kültürü (Ankara: Ötüken, 2015).

82. BOA, Y.PRK.MYD. 12/36-(1893): 'Umum Kürd aşiretleri Milan ve Zilan denilen iki ferdir. Bunlara tahfif ile Mil ve Zil dahi denilir. Cibranlı, Hasenanlı, Heyderanlı aşiretleri aslen Milan; ve Sepki ve Cemedanlı, Zilanlı dahi Zilan așiretlerine mensupturlar. Arab ve müstarebe akvam ve așair bunun haricinde (dir)'.

83. Bedirhan Pasha of Botan and Mir-i Kor of Rewanduz were the most important leaders of uprisings in the region. McDowall, A Modern History of the Kurds, pp. 38-47. Bruinessen, Agha, Sheikh and State, pp.175-81.

84. M. Çadırcı, Tanzimat Döneminde Anadolu Kentleri'nin Sosyal ve Ekonomik Yapıları (Ankara: TTK, 1991), p.194. Takvim-i Vekayi, on 5 Muharrem 1264: 'cenab-ı tacdar eser-i celili olarak bu kere yeni baştan feth ... olmuş (As an achievement of the crowned excellency (Sultan Abdulmecid), this time it (Kurdistan) was reconquered)'.

85. BOA, A.\}MKT.MVL. 23/53 (1847): The central government accepted the suggestion of the governor of Kurdistan that some tribal chiefs should be paid. Heyderan tribe has a müdür and later kaim-i makamlik: BOA, i.MVL 412/17992 (1860), BOA, i.ȘD 40/2066 (1880).

86. Klein, The Margins of Empire, p.129.

87. L. Beck, 'Tribes and the State in Nineteenth- and Twentieth-Century Iran', in Tribes and State Formation in the Middle East, eds. P.S. Khoury and J. Kostiner (Los Angeles: University of California Press, 1990), p.195.

88. Ş. Han, Şerefname, p.302: For Sharaf Khan, the forefathers of Suleymani Emirs were the Arab Umayyad Caliphates and their names came from Sulayman ibn Abd al-Malik (d.717). Ş. Han, Şerefname, pp.394, 396-8: Sharaf Khan tells us that the Rojki tribe of Bidlis region elected Izzeddin, who was living in Ahlat and descendant of Sasanian Emperors, as their Beg/Emir.

89. Milli ỉbrahim Pasha and Heyderani Huseyin Pasha were the best examples for this shifting process. Ekinci, ibid. Klein, ibid.

90. i. Bozkurt, Tarih Boyunca Aşiretçilik ve Şanlıurfa Aşiretleri (Şanlıurfa: I. Bozkurt, 2003), pp.45-6. Local researcher Bozkurt mentions that it was a modern creation but he does not give a time for the creation of this myth. İsmail Sami Pelister, with the code name of Dr Friç, asks why Seref Han did not mention the classification of Mil and Zil which was not yet created in the sixteenth century. Dr Friç, Kürdler: Tarihi ve İçtimai Tedkikat (Istanbul: Tarih Vakfı Yurt, 2014), p.28.

91. 'The tribal Kurds (were) a distinctive conquering race... decidedly look on the tribal Kurds as the superior': FO 424/107 (1880). Major Trotter likened the tribal Kurds to the Scottish Highlanders and non-tribal Kurds to the Scottish Lowlanders: 'These tribes bear a very marked resemblance in many respects to the old Scottish Highland clans, whereas the non-tribal Kurds may, perhaps, be likened to the Lowlanders.'

92. P.S. Khoury and J. Kostiner, 'Introduction: Tribes and the Complexities of State Formation in the Middle East,' in Tribes and State Formation in the Middle East, eds. P.S. Khoury and J. Kostiner (Los Angeles: University of California Press, 1990), pp.1-22. 
93. A. Hourani, 'Conclusion: Tribes and States in Islamic History', in Tribes and State Formation in the Middle East, eds. P.S. Khoury and J. Kostiner (Los Angeles: University of California Press, 1990), pp.303-10.

94. For Bozkurt, Mil was equalized with the southeast Anatolia, while Zil with the eastern Anatolia, Bozkurt, Tarih Boyunca Aşiretçilik, p.23.

95. Halaçoğlu, ibid.

96. Bozkurt, Tarih Boyunca Așiretçilik, p.45. 